\title{
Donacja hrabiów Tollów w przestrzeni wiejskiej Królestwa Polskiego
}

\author{
Donation of the Toll Counts in the Rural Space \\ of the Kingdom of Poland
}

\section{Wprowadzenie}

Po klęsce powstania listopadowego w przestrzeni wiejskiej Królestwa Polskiego pojawiły się majoraty (donacje) ${ }^{\mathrm{r}}$, które przetrwały aż do 1919 r., kiedy to zostały odebrane dotychczasowym rosyjskim właścicielom przez władze odrodzonej Drugiej Rzeczypospolitej². Te „specjalne” majątki ziemskie rozdawane były przez carów w dwóch wyraźnie dających się wyodrębnić okresach, a mianowicie w latach 1835 -1845, po klęsce powstania listopadowego, oraz w latach I866-I871, czyli po stłumieniu insurekcji styczniowej. Patrząc przez perspektywę okresów nadawania tego typu dóbr, można wysnuć wniosek, iż donatariusze otrzymywali je za szczególne zasługi oddane rosyjskim cesarzom w okresie polskich zrywów narodowych ${ }^{3}$. Nagradzanymi byli więc przede wszystkim wojskowi i w nieco mniejszym stopniu cywilni poddani carów - Mikołaja I i Aleksandra II - wywodzący się w zdecydowanej większości z dziedzicznej szlachty rosyjskiej wyznania prawosławnego ${ }^{4}$. W polskiej historiografii począwszy od schyłku XIX w. podejmowano już

I Pojęcia donacja i majorat będą używane w tym tekście jako synonimy. Donacje, czyli darowizny dóbr ziemskich rozdawane były przez carów na zasadach niezbywalności i majoratu, czyli dziedziczenia przez najstarszego syna lub krewnego w przypadku braku potomków w linii męskiej.

2 Dziennik Ustaw 1919, nr 72, poz. 423, Ustawa z dnia 25 lipca 1919 r. w przedmiocie dóbr donacyjnych.

3 W pierwszym z wymienionych okresów dobrami tymi obdarowano 73 generałów, 49 pułkowników i podpułkowników, I kapitana, I3 wysokich urzędników cywilnych i wojskowych oraz 2 lekarzy.

4 W'ród tej grupy byli także tzw. Bałtowie, czyli szlachta pochodzenia nierosyjskiego od kilku co najmniej pokoleń zamieszkująca północno-zachodnie gubernie Cesarstwa Rosyjskiego. Zob. szerzej: A. Szwarc, P. Wieczorkiewicz, O roli tzw. Battów w dziejach Rosji w XIX i XX w. (Na marginesie ksiązki Maksyma M. Duchanowa), „Kwartalnik Historyczny” 1981, nr 4, s. 1067-1082. 
badania poświęcone temu specjalnemu carskiemu rozdawnictwu majątków ziemskich. Można tu wskazać przede wszystkim na pierwszą poważniejszą pracę autorstwa Józefa Kaczkowskiego's czy też niewielkie, ale ważne zestawienie statystyczne opracowane przez Benedykta Bornsteina ${ }^{6}$, w przypadku dawniejszych pozycji. Z kolei z prac w miarę niedawno wydanych na pierwsze miejsce wysuwają się dwie monografie Jerzego Kukulskiego7.

Dobra donacyjne tworzono w Królestwie Polskim na mocy ukazu cesarskiego wydanego 4/16 X I835 r. podczas pobytu Mikołaja I w Warszawie ${ }^{8}$. Powstawały one przede wszystkim na bazie dóbr będących w posiadaniu Skarbu Państwa (ekonomii), a tylko nieliczne utworzono z ziem skonfiskowanych Polakom za udział w powstaniach? Poprzez przekazanie w ręce Rosjan dóbr ziemskich, jako nagrody za osobiste zasługi dla tronu, dążono jednocześnie do utworzenia na tym terenie enklawy rosyjskiej wielkiej własności ziemskiej, która miała przyczynić się do utrwalenia wprowadzonych ograniczeń politycznych i szybciej doprowadzić do unifikacji Królestwa Polskiego z Cesarstwem Rosyjskim. Wedle spisu z I919 r. w przestrzeni dawnego Królestwa Polskiego (bez terenów północnej Suwalszczyzny, która po wojnie przypadła Litwie) było 209 majoratów, które przejęło państwo polskie ${ }^{\mathrm{I}}$.

Jedną z największych donacji przyznanych wojskowym biorącym udział w thumieniu powstania listopadowego, a po jego upadku wchodzącym w skład naczelnych i gubernialnych władz Królestwa Polskiego, bądź piastującym różne wysokie stanowiska w wojsku rosyjskim bądź w administracji centralnej i sądownictwie był majorat Uniejów vel Kościelnica. Dobra ziemskie nadane zostały dziedzicznie generałowi piechoty Karolowi Wilhelmowi hr. Tollowi i w rękach jego potomków (syna i wnuka - obaj nosili imię Aleksander) pozostawały przez osiemdziesiąt lat. To właśnie ten majątek donacyjny położony w regionie Uniejowa nad Wartą oraz władające nim kolejne pokolenia hrabiowskiej rodziny Tollów związanej z tym regionem stały się przedmiotem moich refleksji w niniejszym tekście. $\mathrm{Na}$ temat donatariuszy, rodziny von Tollów, powstał niewielki dwustroni-

5 J.P. Kaczkowski, Donacye w Królestwie Polskim, Warszawa I9I7.

6 B. Bornstein, Majoraty (donacje) w b. Królestwie Polskim, Warszawa 1922 (odbitka z „Miesięcznika Statystycznego”, wydawanego przez Główny Urząd Statystyczny Rzeczypospolitej Polskiej, rok I92I, tom IV).

7 J. Kukulski, Donacje paskiewiczowskie w okresie reform agrarnych, Kielce 1987; tenże, Generatowie carscy i ich majątki ziemskie w Królestwie Polskim (1835-1920), Warszawa 2007.

8 Dziennik Praw Królestwa Polskiego (dalej: DPKP), t. 17, s. 323-367.

9 B. Bornstein, dz. cyt., s. I; J. Kaczkowski, dz. cyt., s. 8I-86.

Io B. Bornstein, dz. cyt., s. 3; Dziennik Ustaw I9I9, $\mathrm{nr}$ 72, poz. 423, Ustawa z dnia 25 lipca I9I9 r. w przedmiocie dóbr donacyjnych. 
cowy tekst autorstwa Tomasza Wójcika zamieszczony w czasopiśmie społeczno-kulturalnym zatytułowanym „W Uniejowie" zawartych korzystali w zasadzie wszyscy dotychczas wspominający o tej rodzinie. W niniejszym tekście znacząco zostały rozbudowane informacje dotyczące członków rodziny von Tollów, a ponadto zostały skorygowane niektóre nieścisłości faktograficzne. Z kolei stosunki osadnicze w obrębie dóbr majorackich $\mathrm{w}$ regionie uniejowskim poddane analizom geohistorycznym znalazły odzwierciedlenie w artykule Moniki Cepil i Tomasza Figlusa. Ten duet autorski szczególną uwagę zwrócił na kwestię przemian osadnictwa wiejskiego pod wpływem realizacji wielkich reform agrarnych skutkujących transformacją układów ruralistycznych wsi w tej donacji ${ }^{2}$. Stąd też te zagadnienia nie stały się przedmiotem moich zainteresowań.

Podjęty w niniejszym artykule temat został zrealizowany w oparciu o materiały źródłowe różnej proweniencji, w tym akta zgromadzone w Archiwum Głównym Akt Dawnych i Archiwum Akt Nowych w Warszawie, Archiwach Państwowych w Łodzi i w Kaliszu. Ponadto wykorzystano ciekawe materiały źródłowe będące w posiadaniu Towarzystwa Przyjaciół Uniejowa (TPU) oraz różnego typu źródła drukowane, a także dawniejszą i najnowszą literaturę przedmiotu. Niestety nie udało się odnaleźć egodokumentów, które wytworzone byłyby przez członków rodziny donatariuszy ani też współczesnych im osób, które wspominałyby kontakty z von Tollami (poza bardzo nielicznymi ze zbiorów ATPU).

\section{Charakterystyka ordynacji}

W myśl art. I ukazu o donacjach z 4/16 X I835 r. dobra donacyjne, które otrzymał generał von Toll, miały stanowić dziedziczną własność prywatną donatariusza ze wszystkimi prawami i użytkami, które przysługiwały skarbowi jako dotychczasowemu właścicielowi tych dóbr. Na własność hrabiego Tolla przechodziły grunty folwarczne i znajdujące się na nich zasiewy, inwentarze żywe i martwe, mlyny, browary, gorzelnie, karczmy i kuźnie oraz dochody z powinności włościańskich. Jednocześnie spod darowizny wyłączona została własność dzierżawców wieczystych oraz włościan zamieszkujących we wsiach, a ponadto magazyny komunalne i inna własność gromadzka lub rządowa, która z mocy art. II i I2 ukazu nadawczego miała nadal pozostawać przy dotychczasowych posiada-

II T. Wójcik, Tollowie, „W Uniejowie. Pismo Towarzystwa Przyjaciół Uniejowa” 2016, nr 67, s. I4-I5.

I2 M.Cepil, T. Figlus, Geneza majoratu istosunki osadnicze w dobrach rodziny Tollów pod Uniejowem,

„Biuletyn Uniejowski” 2017, t. 6, s. 91-107. 
czach $^{13}$. Artykuł 2 gwarantował obdarowanemu posiadanie donacji na zasadzie własności zupełnej z tym jednak, że przyjmował on dobra z różnymi „ścieśnieniami własności” (ograniczeniami), które wypływały z mocy aktów urzędowych wniesionych uprzednio do hipoteki bądź wynikających z przywilejów przysługujących chłopom i kolonistom dóbr skarbowych ${ }^{\mathrm{I4}}$.

Dobra uniejowskie miały przechodzić na następców Karola Wilhelma tylko w drodze spadku. Dla zabezpieczenia praw von Tollów nie wolno było obciążać majoratu nowymi zobowiązaniami, wydzierżawiać, zastawiać lub sprzedawać za długi skarbowe bądź prywatne, ani też przekazywać w drodze alienacji w obce ręce ${ }^{\mathrm{Is}}$. Donatariuszowi pozostawiono całkowitą swobodę w zakresie zarządzania majątkiem, jak i organizacji produkcji rolnej oraz dysponowania uzyskanymi dochodami. Wprowadzano tylko dwa ważne ograniczenia: nadzór nad dobrami sprawowany przez władze skarbowe z tytułu zobowiązań wobec Towarzystwa Kredytowego Ziemskiego oraz obowiązek urządzenia chłopów i prowadzenia prawidłowej gospodarki leśnej w dobrach majorackich ${ }^{\mathrm{I}}$.

W wykazach statystycznych można niestety znaleźć nieco różniące się wielkości powierzchni majoratu przyznanego Karolowi Wilhelmowi hr. Tollowi. W I836 r. majorat miał rozległość 5665 mórg, w tym obszary leśne stanowiły 278I mórg. W świetle wykazu z $1919 \mathrm{r}$ r, kiedy został on przejęty przez władze polskie, wykazywano taką samą jego rozległośćc ${ }^{17}$. Jednak w literaturze przedmiotu pojawia się także jego obszar wyrażony jako I2 088 mórg ${ }^{18}$. Jest to obszar całych dóbr uniejowskich, czyli grunty majoratu wraz ziemią będącą w posiadaniu chłopów zamieszkujących tutejsze wsie. Po uwłaszczeniu ziemia chłopska nie wchodziła w skład majoratu i należy to wyraźnie zaznaczać, a tym samym rozgraniczać, podając właściwą rozległość nadania generałowi von Tollowi. Zziemi włościańskiej donatariuszowi przysługiwały jedynie robocizna, darmochy i czynsze. Darowana donacja miała przynosić $4500 \mathrm{rb}$. rocznego czystego dochodu donatariuszowi. W chwili nadania dobra skarbowe, które stały się podstawą donacji obciążone były

I3 W dzierżawę wypuszczone były m.in. folusz na Warcie, młyn, wiatraki, osada leśna.

I 4 DPKP, t. I7, s. 455-457.

I5 DPKP, t. 17, s. 359-363; J.P. Kaczkowski, dz. cyt., s. 192.

I6 DPKP, t. I7, s. 34I.

17 B. Bornstein, dz. cyt., tab. I, s. I7; tab. 2, s. 25. W opracowaniu J.P. Kaczkowskiego podano nieco inną rozległość w chwili nadania majoratu - 5629 mórg 208 prętów. Por. J.P. Kaczkowski, dz. cyt., tab. s. 444-445.

I8 Jest to rozległość podawana za: Stownik geograficzny Królestwa Polskiego i innych krajów stowiańskich (dalej: SGKP), t. ıо, Warszawa I889, s. 804. Zob.: B. Pełka, Lata zaborów, [w:] Uniejów. Dzieje miasta, red. J. Szymczak, Uniejów-Łódź 1995, s. I8I; M. Cepil, T. Figlus, dz. cyt., s. 93. 
pożyczką w wysokości 33375 rb. udzieloną przez Towarzystwo Kredytowe Ziemskie ${ }^{19}$. Dodatkowo po powstaniu styczniowym, jako rekompensatę za regulacje związane z uwłaszczeniem chłopów, będący wówczas donatariuszem Aleksander hr. Toll, ukazem z I2 IX I866 r. otrzymał niewielką donację - folwark Grzybki z Ekonomii Rządowej Brodnia o rozległości 197 mórg z przysługującą w jego obrębie propinacją, część lasu z leśnictwa Turek oraz daczę Księże Młyny ${ }^{20}$. W I899 r. dochód z wszystkich folwarków donacyjnych szacowano na $25000 \mathrm{rb}$. W $1909 \mathrm{r}$. wszelkie donacyjne nadania ziemskie (Uniejów-Kościelnica i Grzybki) znajdujące się w rękach hrabiów Tollów miały rozległość 5826 mórg 208 prętów. Według danych statystycznych zamieszczonych w opracowaniu Aleksandra Połujańskiego, z pewnością jednego najlepszych dziewiętnastowiecznych znawców gospodarki leśnej, lasy w majoracie Uniejów-Kościelnica w połowie tego wieku zajmowały powierzchnię 2058 mórg 293 pręty (zachodzi różnica w porównaniu do zapisów nadawczych). Były to jedne z największych kompleksów leśnych w skali ówczesnej gub. warszawskiej znajdujące się w rękach donatariuszy ${ }^{21}$.

W skład majoratu nazywanego Uniejów vel Kościelnica w chwili nadania weszły następujące wsie i folwarki: Kościelnica, Orzeszków, Ubysław, Wielenin i Zielenin (Zieleń) oraz wsie Ostrowsko, Człopy, Człopki, Wieścicie, Spicymierz z osadą leśną Malczew, Wola Przedmiejska i Brzeziny ${ }^{22}$. Już w I 838 r. rodzina von Tollów zaczęła zabiegać u władz rządowych o powiększenie nadanej donacji. Domagali się zwrotu ziem skarbowych z dawnej Ekonomii Rządowej Uniejów, zajętych jeszcze w okresie konstytucyjnym Królestwa Polskiego celem regulacji i wyznaczenia osad fabrycznych dla mających osiedlać się w Uniejowie rękodzielników. Ze względu na niemożność przywrócenia stanu pierwotnego sprzed $1824 \mathrm{r}$. do zwrotu placów dla donatariusza jednak nie doszło ${ }^{23}$. W I845 r. ówczesny właściciel donacji Aleksander hr. Toll utworzył kolejny punkt osadniczy wchodzący w skład majoratu, a mianowicie folwark Aleksandrów. Wystawiony został tam

I9 J.P. Kaczkowski, dz. cyt., tab. s. 444-445.

20 DPKP, t. 66, Ukaz do Rady Administracyjnej naszego Królestwa Polskiego, s. 79-83.

2I Czwarte miejsce po majoracie Łęczno (313I mórg 220 prętów), Brwilno (2809 mórg 34 pręty) i Czarnocin (2326 mórg 294 pręty).Zob. A. Połujański, Opisanie lasów Królestwa Polskiego i Gubernij Zachodnich Cesarstwa Rosyjskiego pod względem historycznym, statystycznym igospodarczym, t. I, Warszawa I854, s. 62.

22 Archiwum Państwowe w Łodzi (dalej: AP£), Urząd Gubernialny Kaliski do Spraw Włościańskich (dalej: UGKdSW), sygn. пा Унеев владемьца гр. Толя, Турекскаго уезАа ч. I, bp.; DPKP, t. 20, s. 347 i n.

23 Archiwum Główne Akt Dawnych (dalej: AGAD), Komisja Rządowa Spraw Wewnętrznych (dalej: KRSw), sygn. 1907, Miasto Uniejów, poszyt v, Pismo do dyrektora Głównego Prezydującego W KRSWiD z maja I $838 \mathrm{r}$. 
dworek-rządcówka dla zarządzającego dobrami majorackimi. Budynki folwarczne powstały w dawnych stajniach wojskowych należących w okresie przedpowstaniowym do polskich szaserów.

Aleksander hr. Toll po przejęciu donacji po śmierci ojca, na mocy ukazu carskiego z I835 r., zobowiązany był do uregulowania stosunków z włościanami, a mianowicie zamianę pańszczyzny na czynsz. Regulacja czynszowa pociągała za sobą przewrót $w$ systemie organizacji produkcji rolnej. $\mathrm{Z}$ regulacją czynszową wiązała się także separacja i komasacja gruntów, w rezultacie których nastąpiła likwidacja szachownicy pól chłopskich i folwarcznych. Separacja gruntów stwarzała dominium niejednokrotnie okazję do zaokrąglania posiadłości folwarcznych i koncentrowania najlepszych gruntów, a przekazywaniu włościanom ziemi mniej urodzajnej i gorzej położonej. Regulacje przeprowadzano w donacjach Królestwa Polskiego w latach I839-1859, a pewne przyspieszenie ich tempa nastąpiło po I846 r., co wiązało się z falą oporu chłopskiego przeciwko pańszczyźnie ${ }^{24}$. Nie było to więc zadanie proste, o czym świadczą konflikty, do jakich doszło na linii donatariusz - włościanie. Jednak hrabiowie Toll mogli liczyć w takiej sytuacji na pomoc urzędników i wojska rosyjskiego. W I845 r. w dobrach należących do Aleksandra, syna Karola Wilhelma, doszło do buntu około I50 chłopów. Wspierając hrabiego, naczelnik powiatu kaliskiego wysłał do majątku dziesięciu kozaków, których zadaniem było przywrócenie porządku i zmuszenie włościan do posłuszeństwa. W kolejnych latach A. hr. Toll prowadził długotrwałe spory z mieszkańcami wsi Orzeszków²5. Obciążeń pańszczyźnianych włościan na rzecz donatariusza wówczas nie zniesiono, ale doszło do niewielkich korekt ziemi pomiędzy wsią a folwarkami majorackimi, a ponadto dokonano wymiany niewielkich gruntów $\mathrm{z}$ mieszczanami-rolnikami z Uniejowa ${ }^{26}$.

Po nadaniu części dóbr Ekonomii Rządowej Uniejów Karolowi Wilhelmowi hr. Toll w gestii powstałego majoratu pozostawały most na Warcie oraz siedem innych małych przepraw na jej dopływach. Spadkobierca pierwszego donatariusza, Aleksander hr. Toll, zamierzał pozbyć się kłopotu z utrzymaniem mostu i chciał go przekazać kasie miejskiej Uniejowa. W I864 r. na zamku toczyły się w tej sprawie pertraktacje z udziałem naczel-

24 Zob. J. Kukulski, System organizacji produkcji folwarcznej i zarzadzania dobrami donacyjnymi w Królestwie Polskim, „Acta Universitatis Lodziensis. Folia Historica” 1984, nr I8, s. 59-60.

25 B. Szczepański, Rozwój rolnictwa, [w:] Dzieje Wielkopolski, red. W. Jakóbczyk, t. 2, Poznań I973, s. 785; T. Grabarczyk, A. Kowalska-Pietrzak, J. Szymczak, Uniejowskie strony - kartyzprzesztości odlegtej, nieznanej i bliskiej gminy Uniejów, Łódź-Uniejów 2008, s. I0I.

26 AGAD, KRSW, sygn. I905, Miasto Uniejów, poszyt III, k. I05. W krótkiej notatce z 23 III I849 r. brak jest szczegółowego wyjaśnienia sprawy. 
nika pow. kaliskiego, inżyniera gubernialnego i powiatowego oraz dwóch ławników miejskich: Jana Zajączkowskiego i Jana Strochowskiego ${ }^{27}$. Przedstawicieli społeczności uniejowskiej przekonywano, że opłaty taryfowe przyniosą miastu znaczne korzyści finansowe. Ławnicy jednak odmówili przejęcia mostu, tłumacząc, iż nie mają zgody mieszkańców, zaś miasto nie posiada żadnego lasu, a więc drewna na niezbędne naprawy przeprawy mostowej. W rezultacie Rząd Gubernialny Kaliski (RGK) zdecydował o pozostawieniu mostu nadal w administracji majoratu A. hr. Tolla. Dopiero w latach I880-I882 RGK uwolnił majorat od obowiązku utrzymania mostu i pobierania opłat taryfowych, które wpłacał do Kaliskiej Izby Skarbowej ${ }^{28}$. W 1883 r. RGK przejął zarząd nad mostem, który oddano w dzierżawę osobie prywatnej.

Warto podkreślić, iż kiedy w I858 r. z inicjatywy dawnych klemensowczyków z Andrzejem hr. Zamoyskim na czele i za zgodą cara Aleksandra II powstało Towarzystwo Rolnicze, donatariusz Aleksander hr. Toll stał się jego członkiem. Towarzystwo skupiało w swoim szczytowym okresie (początek I86I) ponad cztery tysiące ziemian i właścicieli ziemskich przede wszystkim z terenów Królestwa Polskiego, a jego naczelnym celem miało być opracowanie zasad reform agrarnych w tej części ziem polskich ${ }^{29}$. Dziedzic uniejowskiego majoratu, jako największy posiadacz ziemski w regionie, również uznat, iż powinien znaleźć się w tym gronie, obok kilku wysokiej rangi carskich urzędników sprawujących rządy w Królestwie Polskim oraz części innych donatariuszy mających majoraty przyznane po powstaniu listopadowym ${ }^{3 \circ}$.

$\mathrm{Na}$ mocy ukazu cara Aleksandra II z 2 III I 864 r. we wsiach położonych w regionie uniejowskim, w tym należących do majoratu ówczesnego donatariusza Aleksandra hr. Tolla, przeprowadzono reformę uwłaszczeniową. Ziemię otrzymali wieczyści dzierżawcy (wpisani do tabel prestacyjnych w I846) oraz dzierżawcy kontraktowi. Z nadziałów wyłączono robotni-

27 AGAD, KRsw, sygn. 1909, Miasto Uniejów, poszyt VII, Pismo Aleksandra hr. Tolla do Naczelnika Powiatu Kaliskiego z I 4 III I864 r.

28 APŁ, Rząd Gubernialny Kaliski (dalej: RGK), sygn. 2334, bp., Ob osvoboždenii vladelaca maioratnogo imenija Koscel>nica-Uneev grafa Aleksandra Tolja ot objazannosti soderžat> v nadležaščej ispravnosti nachodjaščisja v skazannom imenoo mosty.

29 Klemensowczycy to określenie grupy ziemiańskich liberałów, zwolenników modernizacji rolnictwa i stosunków społecznych w Królestwie Polskim. W latach 40. XIXw. z inicjatywy Andrzeja hr. Zamoyskiego w jego dobrach w Klemensowie odbywały się zjazdy ziemian, a po ich zakazaniu przez władze carskie, grupa zwolenników modernizacji skupiła się wokół redakcji pisma „Roczniki Gospodarstwa Krajowego”. Zob. W. Grabski, Historia Towarzystwa Rolniczego I858-1861, t. I-2, Warszawa 1904 .

30 Dodatek Lista cztonków czynnych Towarzystwa Rolniczego w Królestwie Polskim na rok I862, „Roczniki Gospodarstwa Krajowego" I86I, t. 43, poszyt I, s. 34-36; Korespondenci okregowi Towarzystwa Rolniczego w Królestwie Polskim w I86I roku, tamże, s. I17. 
ków najemnych oraz służbę folwarczną. Wywołało to duże zaniepokojenie i pomimo wielu skarg w tej kwestii Komitet Urządzający nie uwzględnił żądań ludności folwarcznej ${ }^{3 x}$. Nadziały we wsiach majoratu A. hr. Tolla przedstawiały się następująco: Brzeziny - 445 mórg 73 pręty, Człopy -747 mórg 20 prętów, Człopki - 178 mórg 89 prętów, Kościelnica - 456 mórg 298 prętów, Orzeszków - 516 mórg 127 prętów, Ostrowsko - I522 morgi 24 pręty, Spycimierz - I38I mórg I83 pręty, Wielenin - 787 mórg I25 prętów, Wieszczyce - 156 mórg 49 prętów, Wola Przedmiejska - 507 mórg 58 prętów ${ }^{32}$. Ogółem włościanom zamieszkującym tereny należące do majoratu hrabiów Tollów przyznano 6788 mórg 136 prętów.

Za utratę przychodów z propinacji w tych wsiach i zmniejszenie się tym samym ogólnego dochodu, który miał uzyskiwać donatariusz (4500 rb.), Aleksander hr. Toll na mocy ukazu carskiego z I866 r. jako rekompensatę otrzymał wspomniany już wcześniej folwark Grzybki z Ekonomii Rządowej Brodnia (dochód roczny 250 rb. 39,5 kop.) i część lasu z leśnictwa Turek (dochód roczny 257 rb. 39,5 kop.) oraz daczę Księże Młyny. Nadanie odbyło się na tych samych zasadach co wcześniejsze darowizny z mocy przepisów ukazu z I835 r.33 Donacja została przekazana Aleksandrowi hr. Tollowi z dniem 9/2I VI I867 r. W świetle sporząadzonego szczegółowego opisu donacji stan zabudowań był określony jako średni i dobry, a najgorszym stanie był budynek mieszkalny. Rozległość gruntów była następująca: gruntów uprawnych - 173 morgi 35 prętów, tąki - 29 mórg 117 prętów, osada dla pastucha - 3 morgi 225 prętów, czyli łączny obszar to 206 mórg 77 prętów. Ponadto nowy donatariusz miał prawo do korzystania ze wspólnego pastwiska położonego na rzeką Wartą (wspólnie z chłopami z wsi Grzybki i Proboszczewice i mieszczanami z Warty). Las z obrębu Księże Młyny o powierzchni 327 mórg 173 pręty został przekazany Aleksandrowi hr. Tollowi 3/15 XI I868 r. ${ }^{34}$

Jeszcze inne zmiany dotyczące rozległości i kształtu terytorialnego majoratu Uniejów-Kościelnica były konsekwencją uwłaszczenia mieszczan-rolników z Uniejowa. Ziemie nadane mieszczanom uniejowskim położone były nieraz w kilku miejscach. Niektóre graniczyły bezpośrednio z gruntami majoratu hrabiów Tollów. W I878 r. w celu likwidacji niewygodnej

3I APŁ, UGKdSW, sygn. 3298, bp., О составлении Аанной на подуховное имение при посаде Унеев - Турекскаго уезда.

32 Archiwum Akt Nowych (dalej: AAN), Ministerstwo Rolnictwa i Dóbr Państwowych, Wydział Majątków Państwowych (dalej: MRDP, wMP), sygn. 5755, Majątek Uniejów; tamże, sygn. 4939, Uniejów, pow. turecki, t. I, Dane z wypisów z ksiąg hipotecznych.

33 DPKP, t. 66, Ukaz do Rady Administracyjnej naszego Królestwa Polskiego, s. 79-83.

34 Archiwum Towarzystwa Przyjaciół Uniejowa (dalej: ATPU), Protokoły przekazania folwarku Grzybki i lasu rządowego w obrębie Księże Młyny, zbiory nieuporządkowane. 
szachownicy gruntów dokonano zamiany: dwudziestu trzech gospodarzy z nadziału z I864 r. dokonało zamiany 55 mórg 153 prętów ziemi w Uniejowie na grunty folwarku Kościelnica oraz trzynastu gospodarzy z Uniejowa Poduchownego zamieniło grunty o powierzchni 22 mórg 54 prętów na inne również z folwarku Kościelnica. Procedura zamiany i pomiaru była skomplikowana, wymagała zgody kilku urzędów władz włościańskich i skarbowych. Władze lokalne formalnie zamianę zatwierdziły w i 883 r., lecz ostateczne postanowienie wydał w $1903 \mathrm{r}$. Wydział Ziemi MSW w Petersburgu35. Zamiany te w pewnym stopniu zlikwidowały szachownice i niekorzystne położenie gruntów, lecz uregulowanie pretensji wszystkich mieszkańców nie było możliwe. Majątkiem donacyjnym von Tollów zarządzali rządcy, a byli nimi m.in. Józef Hoffmajster i Antoni Sukiennicki.

W posiadanie hrabiów Tollów weszły także dobra prywatne Stemplew-Gąsiory, położone w gminie Zelgoszcz pow. tureckiego, przynależące do parafii Wielenin, jako wiano wniesione przez Adelajdę (Adelę) Sommer po ślubie z Aleksandrem, wnukiem pierwszego donatariusza ${ }^{36}$. Dobra Stemplew (Stęplew) w I887 r. miały rozległość 1450 mórg i składały się z folwarków Stemplew, Gąsiory i Swarzeń oraz nomenklatury Gorzew. Folwark Stemplew miał rozległość 853 morgi, w tym grunty orne i ogrody zajmowały 57 I mórg, łąki Is mórg, pastwiska 32 morgi, las zajmował 203 morgi oraz nieużytki 32 morgi. Folwark było bardzo dobrze zabudowany, gdyż było tutaj dziewięć budynków murowanych i dwa domy z drewna. W folwarku stosowano płodozmian czternastopolowy. Z kolei folwark Gąsiory miał rozległość 416 mórg, w tym grunty orne i ogrody zajmowały 217 mórg, tąki 80 mórg, pastwiska 96 mórg, nie było lasów tylko zarośli 2 morgi, nieużytki i place 2I mórg. Wykazywano trzy budynki murowane i dwa domy drewniane. W uprawie stosowano płodozmian ośmiopolowy. Na terenie folwarku znajdowały się pokłady torfu i niewielkie żyły rudy żelaznej. Najmniejszy był folwark Swarzeń mający rozległość I 8 I mórg, w tym grunty orne i ogrody zajmowały 159 mórg, pastwiska 5 mórg, nieurządzony las in mórg oraz nieużytki 6 mórg ${ }^{37}$. W Stemplewie funkcjonowała duża gorzelnia. Jej kierownikiem od 1909 r. był Antoni Sukiennicki. Majątek ten stał się dobrami posagowymi córek Aleksandra hr. Tolla ${ }^{38}$.

35 APŁ, UGKdSW, sygn. 3298 , bp., О составАении Аанной на подуховное имение при посаде Унеев - Турекскаго уезда.

36 Archiwum Państwowe w Poznaniu. Oddział w Koninie (dalej: App oK), Akta hipoteczne Sądu Rejonowego w Turku, sygn. I926, Księga hipoteczna, Stęplew, nr hip. I40.

37 SGKP, t. 2, Warszawa I88I, s. 5II; tamże, t. II, Warszawa I890, s. 335.

38 ATpu, Umowa o udzielenie plenipotencji dla Antoniego Sukiennickiego (1914), zbiory nieuporządkowane; tamże, Umowa dotycząca objęcia kierownictwa gorzelni w Stemplewie przez Antoniego Sukiennickiego (1909), zbiory nieuporządkowane. 
Wnuk pierwszego właściciela donacji uniejowskiej, również Aleksander, należał do grona właścicieli ziemskich, którzy byli inicjatorami przedsięwzięć mających na celu rozwój gospodarki folwarcznej w tej części Królestwa Polskiego. Jedną z inicjatyw, mającą na celu uaktywnienie rolnictwa, handlu i rzemiosła, stały się starania o budowę sieci kolejowej w pow. tureckim i kaliskim w latach I899-I900. Jednym z ciekawszych pomysłów był projekt budowy linii kolejowej Kutno-Koło-Słupca. Grupa ziemian z Aleksandrem hr. Tollem na czele zamierzała utworzyć Towarzystwo Akcyjne Drogi Żelaznej Kutno-Koło-Słupca z kapitałem zakładowym I,8 mln rb. ${ }^{39}$ Przygotowano nawet wstępne kalkulacje dotyczące ilości przewozu płodów rolnych oraz przypuszczalne korzyści z tego tytułu. Kolej ta miała połączyć północne powiaty gub. kaliskiej z linią Kolei Bydgosko-Warszawskiej. Przed I9I4 r. pojawiły się inne jeszcze projekty budowy linii kolejowych łączących Turek z Kaliszem lub Sieradzem, lecz żaden z nich nie doczekał się wstępnej fazy realizacji. Pomimo zaangażowania się w te inicjatywy carskiego donatariusza do realizacji nie doszło. Główną przyczyną zaniechania realizacji tych inwestycji był brak kapitału, a ponadto niechętne stanowisko Petersburga wobec powstawania linii kolejowych na zachodnich rubieżach Królestwa Polskiego graniczących z Niemcami.

\section{Genealogia von Tollów}

Warto nieco uwagi poświęcić genealogii hrabiowskiej rodziny Tollów, która wyraźnie wpisała się w dzieje Uniejowa i regionu uniejowskiego w okresie zaborów, a po $1918 \mathrm{r}$. związała swoje losy z państwem polskim, nie mogąc powrócić do dawnej ojczyzny po przewrocie bolszewickim i zmianie ustroju. Ta wywodząca się z Niderlandów familia w Rosji swoje rodowe majątki miała na terenie Estonii (Arroküll). W dniu 16 grudnia 1836 r. $^{40}$ car Mikołaj I odrębnym ukazem nadał zamek i majorat generałowi piechoty w stanie spoczynku Karolowi Wilhelmowi hr. Tollowi (8 IV 1777 Keskfer - 23 IV I842 Sankt Petersburg). Własnością hr. Tolla były tylko grunty należące do Skarbu Państwa. Natomiast wszystko, co znajdowało się na gruntach włościańskich, magazyny i własności miejskie, pozostało w rękach dotychczasowych właścicieli. Ukaz carski zobowiązywał jednocześnie obdarowanego do oczynszowania chłopów w przeciągu sześciu lat ${ }^{4 x}$. W świetle aktu nadawczego Mikołaja

39 APE, RGK, sygn. 8I4, bp., Po chodatajstvu Boryslavickogo kostel>nogo dozora ob otpuske summy 569 rublej 72 kopeek na postrojku doma dlja kostel $>$ noj prislugi.

40 Objęcie majoratu miało nastąpić jednak od I VI I838 r. DPKP, t. 20, s. 346.

4I APŁ, UGKdSW, sygn. III7, bp., О составлении миквидационных табелей по имению Унеев владельца гр. Толя, Турекскаго уезда ч. I; DPKP, t. 20, s. 347-359; SGKP, t. I2, Warszawa I892, s. 804. 
I donacja została przyznana za szczególne „zasługi Główno-zarządzaiącego kommunikacyą i budowlami publicznemi, Generała piechoty, Generała-Adiutanta Hrabiego Toll"42. Zasługi te były dla cara rzeczywiście ważne, gdyż donatariusz brał aktywny i pierwszoplanowy udział w skutecznym tłumieniu powstania listopadowego, chociaż może w jakimś stopniu przyczyniła się do otrzymania tej nagrody również jego krótkotrwała praca nad początkami rozwoju kolejnictwa w Rosji ${ }^{43}$. Nadany majorat był jednym z największych wówczas stworzonych na terenie Królestwa Polskiego ${ }^{44}$. $\mathrm{O}$ tym, jak jednoznacznie postrzegano po latach donacje nadane przez carów Mikołaja I i Aleksandra II swoim zasłużonym wysokiej rangi oficerom i urzędnikom, świadczy chociażby preambuła Dekretu Rady Regencyjnej w przedmiocie dóbr donacyjnych z 4 XI 1918 r., w której zapisano: „My, RADA REGENCYJNA KRÓlESTWA POLSKIEGO, zważywszy, że znaczne obszary dóbr, własność skarbu polskiego stanowiących, dla celów krzewienia w Polsce obcej narodowości i wiary oraz przeciwdziałania naszym dążeniom narodowym i wolnościowym, w różnym czasie przez ukazy cesarzów rosyjskich oddane były w posiadanie osobom, które się w walce przeciwko Narodowi Polskiemu wyróżniły, [...]"45.

Jak przebiegała kariera obdarowanego uniejowskim majoratem K.W. hr. Toll? Osiągnąt on znaczącą pozycję w wojsku carskim, podobnie jak dziesiątki innych osób niebędących rodowitymi, prawosławnymi Rosjanami w XVIII i XIX w., tzw. Bałtów (szlachty bałtyckiej) ${ }^{46}$. Jako młody oficer, absolwent Korpusu Kadetów w Sankt Petersburgu uczestniczył w walkach z Napoleonem Bonaparte. Dalsza jego kariera wojskowa szybko postępowała. W I829 r. jako szef sztabu armii naddunajskiej Iwana Dybicza uczestniczył w wojnie z Turcją. Za zasługi w tej zwycięskiej kampanii car Mikołaj I nadał mu dziedziczny tytuł hrabiowski ${ }^{47}$. Następnym eta-

42 DPKP, t. 20, s. 347.

43 Na ten drugi czynnik mocno wskazują potomkowie carskiego generała. Zob. ATPU, Listy Tatiany Toll-Yarygin, zbiory nieuporządkowane. Z drugiej strony, portret gen. Karola Wilhelma hr. Tolla wisi w galerii Pałacu Zimowego w Sankt Petersburgu pośród najwybitniejszych dowódców rosyjskiego imperium.

44 J. Kukulski, Generatowie carscy..., s. 86; tenże, Donacje paskiewiczowskie..., s. 162 i n. W I836 r. drugi tak duży majątek otrzymał jeszcze gen. kawalerii Cyprian A. Kreytz, który został właścicielem donacji utworzonej z dóbr rządowych w Kole (Kościelec).

45 Dziennik Ustaw 1918, nr 15, poz. 35, Dekret Rady Regencyjnej w przedmiocie dóbr donacyjnych, s. 89.

46 Zob. szerzej: A. Szwarc, P. Wieczorkiewicz, dz. cyt., s. 1067-1082; Ł. Chimiak, Kariery tzw. Battów w rosyjskiej administracji Królestwa Polskiego w drugiej potowie XIX w., „Przegląd Historyczny" 1997 , t. 88, nr 3-4, s. 44I-458.

47 T. von Bernhardi, Denkwürdigkeiten aus dem Leben des Grafen von Toll, 2. Auflage, Bd. 3, Leipzig I866, passim; Ch. von Toll, Die Familie von Toll - eine Adelsfamilie im Ostseeraum, s. 219, [dostęp: 22 lutego 2020]. Dostępny w internecie: http://toll-europe.se/Artiklar/toll-runt-oestersjon-de.pdf. 
pem w jego służbie wojskowej stał się udział w wojnie polsko-rosyjskiej w I83 I r. Kiedy armia carska wkroczyła w granice Królestwa Polskiego, K.W. hr. Toll pełnił nadal funkcję szefa sztabu armii feldmarszałka Dybicza. To on doradzał głównodowodzącemu armii carskiej w bitwie pod Grochowem (25 lutego) i stał na czele szarży kawalerii rosyjskiej pod Olszynką Grochowską. Namawiał I. Dybicza, aby po bitwie natychmiast zaatakować Warszawę, co mogło przynieść powodzenie wojskom carskim i szybkie zdławienie polskiego powstania. Z kolei jako dowodzący rosyjską piechotą walnie przyczynił się do pokonania wojsk polskich w bitwie pod Ostrołęką (26 maja). Po śmierci I. Dybicza, do chwili przybycia nowego wodza naczelnego Iwana Paskiewicza, przez krótki czas dowodził armią rosyjską. $\mathrm{U}$ boku nowego wodza naczelnego uczestniczył w dalszych walkach. To właśnie gen. Toll był głównym autorem tzw. „manewru Paskiewicza”, czyli strategicznego obejścia polskich pozycji od północy i przeprawy przez Wisłę pod Włocławkiem, oraz autorem planu udanego szturmu Warszawy we wrześniu I831 r. ${ }^{8}$ Ze służby wojskowej odszedł w I8 33 r. w stopniu generała piechoty ze względu na pogarszający się stan zdrowia i wstąpił do służby cywilnej, poświęcając się przede wszystkim pracy na rzecz rozwoju kolejnictwa w Rosji. W tym względzie napisał dokument pt. „Memorandum hrabiego Tolla o kolejach". Cywilna służba K.W. hr. Tolla zyskała uznanie w oczach cara Mikołaja I, który w I835 r. odznaczył generała brylantowym orderem św. Andreja Pierozwannogo ${ }^{49}$. Obdarowany majoratem na terenie Królestwa Polskiego K.W. hr. Toll najpewniej nigdy w Uniejowie nie był, gdyż stan zdrowia nie pozwalał mu już na dalekie wyjazdy poza stolicę Rosji i Estonię. Korzystał jednak najpewniej z dochodów uzyskiwanych z przyznanych dóbr ziemskich. Natomiast zamek uniejowski, w którym zamieszkał pierworodny syn Aleksander z rodziną, odwiedzała żona obdarowanego generała hr. Karolina Olga von Strandmann, córka i siostra generałów armii carskiej. Karol Wilhelm zmarł w Sankt Petersburgu 23 IV I842 r. i został pochowany w Arroküll. Z małżeństwa ze wspomnianą Karoliną Olgą von Strandmann (I2 VIII 1796 - 7 VII I86I), zawartego w I8I4 r., doczekał się czterech synów: Aleksandra (20 VII I8I6 St. Petersburg -I892 Uniejów), Konstantego (22 X I817 St. Petersburg - I3 II 1884 Arroküll) so,

48 O poważnej roli odgrywanej przez gen. Karola Wilhelma hr. Tolla w wojnie i 83 I r. zob. szerzej: W. Tokarz, Wojna polsko-rosyjska 1830 i 183 I, Warszawa 1930, passim.

49 T. von Bernhardi, dz. cyt., Bd. 4, passim; R.M. Hayward, Russia Enters the Railway Age, $1842-1855$, New York 1998, s. 42-47.

50 Radca kolegialny, objął majątek rodowy w Arroküll. Jego kolejnymi żonami były kobiety ze znakomitych książęcych rodów: Zenaida Golicyn (I8I7-I845) - ślub w i845 r. i Katarzyna Dolgorukow (6 XII I825-3I X I899) - ślub w I853 r. 
Mikołaja (3 VII I819 St. Petersburg - 2 XI i880 Heidelberg) ${ }^{\text {sI }}$ i Karola Wilhelma jr (I2 VIII I834 St. Petersburg - 2 II I893 Kopenhaga) ${ }^{\text {s2 }}$ oraz trzech córek: Elżbiety (23 IX I82I St. Petersburg - 2 IX I865 Dürkheim), Aleksandry (Aleksandrieta) (5 II I83I St. Petersburg - 5 IX I89I Steingaden) i He-

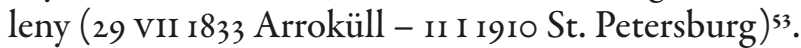

Po śmierci ojca majorat, zgodnie z zasadą dziedziczenia, przypadł pierworodnemu synowi Aleksandrowi (I816-1892). On to związał swoje losy $\mathrm{z}$ regionem uniejowskim, który najpewniej przypadł mu do gustu, a z pewnością magnesem był rozległy majątek. Żadne z jego rodzeństwa nie zamieszkało w uniejowskim zamku, chociaż nie można odrzucić przypuszczenia, iż bywali tu niejednokrotnie z wizytami. Pierworodny syn Karola Wilhelma był pierwszym z rodu von Tollów wyznania prawosławnego, gdyż zgoda ojca na konwersję potomka z protestantyzmu na prawosławie była wymogiem, aby sam car Aleksander I trzymał swojego imiennika do chrztu. Nowy dziedzic uniejowskiego majoratu podjął się remontu zamku, który został też otoczony rozległym, urokliwym parkiem, do którego sprowadzano różne drzewa i rośliny ${ }^{54}$. $\mathrm{Z}$ jego inicjatywy wybudowana została kaplica nazywana przez uniejowian cerkwią. Należy przypuszczać, że zainteresowanie pierwszego z hr. Tollów, który zamieszkał w regionie uniejowskim, samym miastem było raczej niewielkie. Pod pojęciem Uniejów rozumiał on raczej swój majorat i zabytkowy zamek niż mocno podupadłą mieścinę.

W Uniejowie z małżeństwa z Anną von Loeben (1819-1863), zawartego w lutym 1838 r., urodziły się dzieci, w tym pierworodny syn, również Aleksander (19 VI I84I Uniejów - 24 XI I9I8 Warszawa), który przejmie w przyszłości majorat po ojcu. Pozostałe dzieci to: Włodzimierz (I6 VIII I842 Uniejów - I4 VII I870 Reichenhall), Olga (20 II I844 - I5 VIII I9OI Freienwalde), Zenaida (27 VIII I 846 - I857), Sergiusz (30 VI I848 St. Petersburg - 19 I 1923 Baden-Baden) 55 .

5I Był generałem lejtnantem w armii carskiej. Na mocy ukazu Aleksandra II z 25 I 1868 r. otrzymał donację o rozległości 2597 mórg 204 pręty, składającą się z folwarków Ostrowąs i Gęsin w pow. włocławskim, Leszczydół w pow. pułtuskim i części lasu z leśnictwa wyszkowskiego, która przynosiła $1500 \mathrm{rb}$. rocznego dochodu. W 1870 r. poślubił Katarzynę Igantiew. W 1909 r. ich syn Eugeniusz hr. Toll odziedziczył ten majorat. J.P. Kaczkowski, dz. cyt., s. 298, 488-489.

52 Był rosyjskim ambasadorem w Kopenhadze. Jego żoną od I858 r. była Helena von Strandmann (I834-28 VII 1910) wywodząca się z rodziny spokrewnionej z von Tollami.

53 T. von Bernhardi, dz. cyt., Bd. 4, passim; Genealogisches Handbuch der baltischen Ritterschaften, Teil 2: Estland, Görlitz I93o, s. 434-435; J. Kukulski, Generatowie carscy..., passim; T. Wójcik, dz. cyt., s. I4-16; Ch. von Toll, dz. cyt.. s. 219-220.

54 Wojewódzki Urząd Ochrony Zabytków, nr rejestru A/48I/222, Park w zespole zamkowo-pałacowym w Uniejowie, II poł. XIX w.

55 Sergiusz hr. Toll przebywał poza Uniejowem. W latach 1889-1903 był gubernatorem cywilnym Sankt Petersburga, a od I903 r. był członkiem Rady Państwa. W I9I 4 r. uzyskał tytuł wielkiego 
Kolejny z von Tollów, ostatni dziedzic uniejowskiego majoratu, również Aleksander (I84I-I9I8), wnuk Karola Wilhelma, urodzony i wychowany w Uniejowie, czuł się z miastem jeszcze bardziej związany niż ojciec. Związek małżeński z katoliczką, Adelajdą (Adelą) Sommer (zm. w grudniu 1926 w Bydgoszczy), zawarty 24 VII I874 r. w Dreźnie ${ }^{56}$, mógł wpływać na jego ekumeniczne podejście do religii, m.in. podarował parafii uniejowskiej ziemię na cmentarz grzebalny. Podobno w kościele wisiał herb hrabiowski Tollów, co wskazywałoby na zrośnięcie się rodziny z tą ziemią.

Jednakowe brzmienie imienia ojca i syna - Aleksander - nie pozwala dokładnie na wskazanie, o którego z nich chodzi w przypadku różnych zdarzeń zachodzących w 2 poł. XIX w. Właściciele rozległego majoratu starali się podejmować współpracę z polskim ziemiaństwem. Przejawem tego było chociażby przystąpienie do Towarzystwa Rolniczego (I858-I86I) skupiającego ponad cztery tysiące właścicieli ziemskich przez Aleksandra - ojca, gdyż Aleksander - syn był jeszcze niepełnoletni. Jednak, który z nich uczestniczył z sukcesami w różnych wystawach rolniczych organizowanych po powstaniu styczniowym, nie można już jednoznacznie wskazać. Tytułem przykładu podczas wielkiej Wystawy Przemysłowo-Rolniczej, która odbyła się w Warszawie we wrześniu I874 r., jeden z Aleksandrów hr. Toll zaprezentował odmiany nasion sosny i świerku pochodzące ze szkółek leśnych zaprowadzonych w majorackich lasach, a ponadto wystawiał w konkursie tryki i maciory wyhodowane w uniejowskich/kościelnickich dobrach ${ }^{57}$.

W gościnie na zamku von Tollów w Uniejowie bywała warszawska śmietanka towarzyska, bawiono się tutaj, ucztowano i polowano. W I894 r. na łamach „Kalendarza Myśliwskiego Ilustrowanego” podano informację, iż „28 i 29 grudnia I892 roku odbyło się w Uniejowie w majątku hrabiego Tolla polowanie. Zabito 132 zające, 3 rogacze, I2 bażantów i 2 lisy"s8. Należy przypomnieć, iż właśnie w tymże $1892 \mathrm{r}$. zmarł Aleksander - senior. Hrabiów Tollów odwiedzali również przejeżdżający przez Uniejów Rosjanie i przedstawiciele innych narodowości pozostający w służbie carskiej, których było wielu. Warto wspomnieć chociażby wizytę/wizyty Carla Gustafa Mannerheima, późniejszego generała carskiego, a następnie

łowczego. W I876 r. poślubił Zofię Tołstoj (30 IX I856-I4 II 1917). Genealogisches Handbuch der baltischen..., s. 434-435; Ch. von Toll, dz. cyt., s. 220.

56 Genealogisches Handbuch der baltischen..., s. 435. Podawane jest również jej imię - Anna.

57 AGAD, Komitety wystawowe, seria 2, Komitet Ogólny Wystawy Rolniczej w Warszawie, ı874, sygn. II, bp., Deklaracje udziału w wystawie w ramach Oddziału I Sekcji Rolniczej; Kronika ekonomiczna, „Noworocznik Kaliski na rok przestępny i876”, Kalisz I875, s. 48.

58 Kronika myśliwska (I892-1893), „Kalendarz Myśliwski Ilustrowany na rok I894”, Warszawa I893, s. I73. 
regenta i prezydenta Finlandii. W latach 1889-1890 służył on jako kornet ${ }^{59}$ w I5. Aleksandryjskim Pułku Dragonów stacjonującym wówczas w Kaliszu, a następnie, w 1909 r., powrócił do Królestwa Polskiego (najpierw dowódca I3. Włodzimierskiego Pułku Ułanów i od I9II r. dowódca Lejb-Gwardyjskiego Pułku Ułanów Jego Cesarskiej Mości). Okolice Uniejowa (chociaż przede wszystkim Spały i Białowieży) należały do jego ulubionych terenów łowieckich ${ }^{60}$.

Kiedy w I892 r. zmarł Aleksander, syn Karola Wilhelma, pochowany został w Uniejowie w specjalnie zbudowanej świątyni na planie greckiego krzyża, czyli cerkiewce. Pogrzeb stał się ważnym wydarzeniem dla mieszkańców ówczesnej osady. Obok niego w podziemnej krypcie cerkiewki spoczęła także jego żona Anna von Loeben hr. Tollowa oraz Wanda hr. Toll, pierwsza żona ich syna Sergiusza, wnuka Karola Wilhelma ${ }^{61}$.

Hrabiowie Tollowie mieszkali w zamku w Uniejowie do wybuchu I wojny światowej. Aleksander, wnuk Karola Wilhelma, ze związku z Adelajdą (Adelą) Franciszką Sommer doczekał się pięciorga potomków: Anny (II V I876 - I964), Aleksandra (8 IV I877 - I945 Bydgoszcz), Zenaidy (II I 1879 Uniejów - luty 1935 Bydgoszcz), Eugeniusza (I4 II I880 - wrzesień 1939 Warszawa) i Sergiusza (22 XI 1893 Warszawa - 19 XII 1961 Katowice) ${ }^{62}$. Nie wszystkie jednak z tych dzieci przyszły na świat w Uniejowie. Przed wybuchem Wielkiej Wojny to Eugeniusz von Toll sprawował będzie pieczę nad głównym kluczem majątkowym Uniejów-Kościelnica, gdyż pierworodny Aleksander (prawnuk Karola Wilhelma) robił karierę, podobnie jak pradziad, w wojsku carskim uzyskując rangę generała. Własnością posagową pań z rodziny von Tollów był majątek Stemplew-Gąsiory, na którym zapisane były przed wybuchem I wojny zobowiązania dla ich siostry Zenaidy.

Wśród członków rodziny byli wysokiej rangi oficerowie armii carskiej, stąd też w obawie przed represjami niemieckimi wraz z wybuchem wojny wyjechali oni z majątku. Przed opuszczeniem pałacu, I7/30 VII I9I4 r. donatariusz Aleksander, wnuk Karola Wilhelma, wraz ze swoją żoną Adelajdą (Adelą) zawarli umowę z dotychczasowym kierownikiem gorzelni w Stemplewie (od 1909 r.), Antonim Sukiennickim, przekazując mu generalne plenipotencje do zarządzania majątkami Uniejów-Kościelnica

59 Najniższy stopień oficerski w formacjach carskiej kawalerii.

60 C.G. Mannerheim, Wspomnienia, tłum. K. Szelągowska, Warszawa 2017, passim.

6I Za datę powstania „Uniejowskiej Cerkiewki” przyjmuje się rok i885. Usytuowana została w lesie nieopodal drogi Uniejów-Dąbie przy miejscowości Orzeszków Kolonia. Szerzej zob. M. Zdyb, Kaplica grobowa rodziny Tollów jako przyktad prawostawnego dziedzictwa w województwie tódzkim, „Biuletyn Uniejowski” 2017, t. 6, s. 225-236.

62 Genealogisches Handbuch der baltischen..., s. 435; Ch. von Toll, dz. cyt., s. 219-220. 
z przyległościami i Stemplew z przyległościami. Analiza umowy wskazuje, iż rządca otrzymał bardzo szerokie uprawnienia, także w kwestiach finansowych. Tytułem zabezpieczenia warunków pełnomocnictwa A. Sukiennicki wpłacił małżonkom von Tollom kaucję w gotówce w wysokości 6 tys. rb., którą mieli mu zwrócić po rozwiązaniu umowy. W chwili wybuchu działań wojennych A. Sukiennicki przeniósł się do dworu w Stemplewie, gdzie zamieszkiwał do $1916 \mathrm{r}$. Wówczas decyzją niemieckich władz okupacyjnych nakazano mu opuścić teren dawnej gub. kaliskiej ${ }^{63}$. Jeszcze w I9I5 r. władze niemieckie zdecydowały się na konfiskatę majoratu Uniejów-Kościelnica ${ }^{64}$. Z kolei z końcem Wielkiej Wojny i odzyskaniem niepodległości przez Rzeczpospolitą formalnie majoraty i donacje, będące wcześniej w posiadaniu rosyjskich właścicieli, zostały zlikwidowane ${ }^{65}$. Jedynie majątek Stemplew-Gąsiory pozostał w posiadaniu rodziny hr. Tollów, ale w 1930 r. został on zakupiony przez inż. Wiesława Gerlicza ${ }^{66}$ (chociaż w wykazie właścicieli ziemskich w woj. łódzkim wpisany jest Michał Toll, którego nie ma w genealogii uniejowskiej linii von Tollów).

Ostatni z dziedziców Uniejowa z rodziny hr. Tollów, Aleksander, wnuk Karola Wilhelma, zmarł 24 XI I9I8 r. w Warszawie w wieku 77 lat. Został pochowany na Wolskim Cmentarzu Prawosławnym w Warszawie ${ }^{67}$. Po utracie majorackich dóbr wdowa po nim Adelajda (Adela) z Sommerów hr. Toll W 1920 r. wraz z czwórką dorosłych dzieci osiadała w Bydgoszczy, która stała się nową ojczyzną także dla licznej grupy byłych carskich oficerów i uciekinierów z bolszewickiej Rosji. Tylko Eugeniusz hr. Toll zamieszkał w Warszawie. Adelajda hr. Toll zmarła w grudniu 1926 r. po nieszczęśliwym upadku ze schodów i pochowana została w Bydgoszczy na cmentarzu Nowofarnym (wspomnienie o niej pojawiło się w „Dzienniku Bydgoskim”). W I93I r. potomkowie Aleksandra i Adelajdy (Adeli) hr. Toll decyzją Sądu Okręgowego w Kaliszu stali się współwłaścicielami majątku Zagaj-Mizerka

63 AтрU, Umowa o udzielenie plenipotencji dla Antoniego Sukiennickiego (I9I 4), zbiory nieuporządkowane; tamże, Umowa dotycząca objęcia kierownictwa gorzelni w Stemplewie przez Antoniego Sukiennickiego, zbiory nieuporządkowane.

64 Archiwum Państwowe w Kaliszu, Naczelnik Powiatu Kaliskiego [Deutscher Kreischef in Kalisch] I9I5-I918, sygn. 310, Majoratsforsten [Lasy ordynackie], k. I-44. Konfiskacie miał podlegać także majątek w Stemplewie.

65 W I9I9 r. majorat hrabiów Tollów został przejęty przez Ministerstwo Rolnictwa i Dóbr Państwowych. Na mocy art. I3 Ustawy z dnia 25 lipca 1919 r. w przedmiocie dóbr donacyjnych, członkowie rodziny von Tollów mogli zatrzymać tylko przedmioty osobiste, które nie zostały uznane, że „stanowią przynależność dóbr donacyjnych”. Dziennik Ustaw 1919, nr 72, poz. 423, s. 78I.

66 APP OK, Akta hipoteczne Sądu Rejonowego w Turku, sygn. 1926, Księga hipoteczna, Stęplew, nr hip. I 40.

67 Nekrolog, „Kurier Warszawski” 1918, nr 327, s. 5. 
w pow. tureckim, wydzielonego z dóbr państwowych Uniejów-Kościelnica ${ }^{68}$. Anna z Tollów de Reinhard, Zenaida z Tollów de Wetter-Rozental, Aleksander Toll, Sergiusz Toll i Eugeniusz Toll posiadali hipotecznie zapisany majątek o rozległości 463 mórg 65 prętów (czyli 263 ha $3500 \mathrm{~m}^{2}$ ). Na majątku tym ciążyły jednak dosyć wysokie zobowiązania wobec różnych osób ${ }^{69}$.

Zwięźle chciałbym jeszcze przybliżyć, jakie były dalsze losy przedstawicieli uniejowskiej gałęzi von Tollów po 1918 r., a były one dosyć pogmatwane i każde z prawnuków Karola Wilhelma von Tolla po śmierci spoczęło w innym miejscu. Anna hr. Toll zawarła 20 II 1905 r. w Warszawie związek małżeński z przyszłym generałem carskim Iwanem (Janem) Reinhardtem (II VIII I864-I927). W latach I902-I904 w stopniu pułkownika pełnił on obowiązki wicegubernatora guberni piotrkowskiej, a wcześniej od I899 r. pracował w kancelarii general-gubernatora warszawskiego. I. Reinhardt pochodził z potomstwiennych dworian guberni kowieńskiej o niemieckim rodowodzie, a jego ojciec Aleksander Reinhardt był generałem armii carskiej. Mąż Anny hr. Toll awans na stopień generała majora uzyskał w grudniu $1908 \mathrm{r}$. W I9I4 r. został uwolniony ze służby wojskowej celem objęcia urzędu wicegubernatora radomskiego ${ }^{7 \circ}$. I. Reinhardt zmarł w Bydgoszczy w $1927 \mathrm{r}$. i został pochowany na istniejącym wówczas cmentarzu ewangelickim przy ul. Jagiellońskiej. Anna z hr. Tollów Reinhardt wyjechała do Londynu, a jej potomkowie żyją w Angliii"

Jej młodsza siostra Zenaida hr. Toll była także żoną carskiego generała Henryka von Wetter-Rosenthal (22 VII I864 Sipp - 1927 Bydgoszcz) ${ }^{72}$. Jej mąż przed wybuchem Wielkiej Wojny był dowódcą fortecy w Grodnie, natomiast podczas tej wojny powołano go na komendanta wojennego Czerniowiec w okupowanej Bukowinie. Zenaida w okresie międzywojennym udzielała się społecznie głównie na niwie działalności charytatywnej. Zmarła w Bydgoszczy w lutym $1935 \mathrm{r}$. i pochowana została według obrządku prawosławnego, obok męża i szwagra I. Reinhardta, na cmentarzu

68 AAN, MRDP. WMP, sygn. 5322, Zagaj-Mizerka folw. - (woj. łódzkie) i „Folusz-Papiernia” (pow. turecki) b. donacji Kościelnica Uniejów; APP OK, Akta hipoteczne Sądu Rejonowego w Turku, sygn. 1925, Księga hipoteczna, Zagaj-Mizerka, nr hip. 50.

69 ATPU, Wypis z wykazu hipotecznego majątku „Zagaj-Mizerka” powiatu tureckiego z dn. I6 V I93 I r., zbiory nieuporządkowane.

70 Za swoje zasługi został odznaczony orderami: św. Stanisława 2 kl. (1904), św. Anny 2 kl. (1906), św. Włodzimierza 3 kl. (I9I4). AP£, Rząd Gubernialny Piotrkowski, Wydział Administracyjny, sygn. 6870, O służbie piotrkowskiego wicegubernatora Jana Reinhardta, k. I-8; Cnucoא генералам по стариинству, исправлено по г мая I9II, Санкт Петербург і911.s. 722; Список генералам по старшинству, исправлено по г мая гіл4, Санкт Петербург г914, s. 533.

7I Genealogisches Handbuch der baltischen..., s. 435.

72 Tamże. 
ewangelickim przy ul. Jagiellońskiej w mieście nad Brdą. Po grobach nie ma śladu, gdyż nekropolia ta została zlikwidowana w latach 50. XX w. i na jej miejscu powstał Park Ludowy im. W. Witosa ${ }^{73}$. Jej jedyna córka Olga von Wetter-Rosenthal, urodzona w Warszawie w 1908 r., według wspomnienia o jej matce zamieszczonego na łamach „Dziennika Bydgoskiego”, miała być żoną Polaka inż. Juliana Mariana Piaseckiego ${ }^{74}$, niezmiernie zasłużonego dla rozwoju kolejnictwa w Drugiej Rzeczypospolitej, za co otrzymał Krzyż Komandorski z Gwiazdą OOP w 1938 r., wiceprezesa Zarządu Francusko-Polskiego Towarzystwa Kolejowego z siedzibą w Bydgoszczy. Jednak w jego biogramie zamieszczonym w „Polskim Słowniku Biograficznym” jako żona występuje Maria Jadwiga ze Zbyszyńskich ${ }^{75}$.

Aleksander hr. Toll, prawnuk Karola Wilhelma, poszedł w ślady swojego przodka. W czasie I wojny światowej był dowódcą 2. Pułku Lejb-Huzarskiego Pawłogradzkiego Imperatora Aleksandra III w stopniu generała brygady ${ }^{76}$. Po zakończeniu Wielkiej Wojny podjął aktywną działalność społeczną w Bydgoszczy. W I925 r. wespół z Janem Szpiganowiczem stanął na czele powołanego wówczas do życia w tym mieście Bractwa Prawosławnego. Przyczynił się do utworzenia parafii prawosławnej w mieście nad Brdą i urządzenia cerkwi domowej p.w. Św. Mikołaja Cudotwórcy. Dzięki swoim licznym kontaktom wspierał uchodźców z bolszewickiej Rosji. Obok innego generała carskiego, Aleksandra Karnickiego, był najbardziej znanym przedstawicielem rosyjskiej diaspory. W dniu 3 sierpnia 1926 r. na lamach „Dziennika Bydgoskiego” zamieścił list do redakcji podpisany „Aleksander hr. Toll, generał byłej armii rosyjskiej”, w którym bronił honoru niesłusznie oskarżanego o szpiegostwo brata Eugeniusza, zamieszkałego w Warszawie ${ }^{77}$. W 1945 r. został aresztowany przez komunistów i osadzony w obozie pracy w Bydgoszczy, gdzie zmarł. Był żonaty z Olgą, ze związku tego nie przyszły na świat dzieci.

Eugeniusz hr. Toll przed I9I $8 \mathrm{r}$. był kamerjunkrem dworu cesarskiego Mikołaja II. Przez kilka lat zatrudniony był w kancelarii generał-gubernatora

73 Śp.gen. de Wetter-Rozentalowa, „Dziennik Bydgoski”, 26 II 1935, nr 47, s. 9.

74 Tamże.

75 Monitor Polski 1938, nr 258, poz. 592, Zarządzenie o nadaniu Wielkiej Wstęgi Orderu Odrodzenia Polski, Krzyża Komandorskiego z Gwiazdą Orderu Odrodzenia Polski, Krzyża Komandorskiego Orderu Odrodzenia Polski, Krzyża Oficerskiego Orderu Odrodzenia Polski oraz Krzyża Kawalerskiego Orderu Odrodzenia Polski. Julian Piasecki (ur. 1896), dawny legionista, związany z obozem piłsudczykowskim i Obozem Zjednoczenia Narodowego. Mjr dyplomowany saperów, wiceminister komunikacji. Zginął w walce podczas powstania warszawskiego (3 VIII 1944). Zob. J. Kubiatowski, Piasecki Julian Marian, [w:] PSB, t. 25 , Wrocław 1980, s. $780-782$.

76 Genealogisches Handbuch der baltischen..., s. 435 .

77 Listy do redakcji, „Dziennik Bydgoski”, 3 VIII 1926, nr 175, s. IO. 
warszawskiego Gieorgija Skałona (1905-1914) ${ }^{78}$. Po Wielkiej Wojnie jako jedyny z rodzeństwa nie wybrał Bydgoszczy jako miejsca dalszego zamieszkiwania, tylko osiadł w Warszawie. W 1926 r. miał otrzymać nominację na delegata Ministerstwa Wyznań Religijnych i Oświecenia Publicznego przy metropolicie prawosławnym. Na lamach prasy przypomniano jednak wówczas, iż rok wcześniej był on oskarżony o udział w aferze szpiegowskiej i w lutym 1925 r. na kilka tygodni osadzono go nawet w areszcie. Pomimo że został z tych zarzutów oczyszczony, to z nominacji tej nic nie wyszło. $\mathrm{Na}$ łamach prasy podkreślano jednocześnie jego rosyjskie pochodzenie ${ }^{79}$. Eugeniusz hr. Toll zginął tragicznie podczas bombardowania Warszawy we wrześniu 1939 r. Jego żoną była Ludmiła z baronów Tiesenhausen, a małżeństwo zostało zawarte 4 XI 1912 r. w Warszawie. Ze związku tego urodziła się trójka dzieci: Helena (ur. 26 X 1913), Tatiana (23 VI 1920 r. Stemplew - luty 2013) i George - Jerzy (20 IX 1923-9 IV 2005). Helena, począwszy od 1934 r. do wybuchu powstania warszawskiego, zatrudniona była w Wydziale Ewidencji Ludności Zarządu Miejskiego m. Warszawy. Tutaj poznała swojego męża - Antoniego Latoszka, którego poślubiła w 1943 r. A. Latoszek został zamordowany przez Niemców w pierwszych dniach powstania warszawskiego na Woli. Jej młodsza siostra, Tatiana, poznała swojego męża Jurija Yarigina podczas pobytu w obozie przejściowym na terenie zachodnich Niemiec. Wyjechali razem do USA, gdzie zmarła w lutym 2013 r. Najmłodszy z rodzeństwa George (Jerzy) poślubił S. Jakuszew, z którą jako jedyny z rodzeństwa doczekał się dzieci. Żona Eugeniusza hr. Toll, Ludmiła, wraz z dziećmi opuściła okupowaną Warszawę i wyjechała na Zachód. Potomkowie Eugeniusza hr. Tolla wyemigrowali ostatecznie do USA ${ }^{80}$.

Najmłodszy z prawnuków pierwszego donatariusza, Sergiusz hr. Toll, był wybitnym entomologiem, chociaż ukończył również studia prawnicze i to w tej drugiej dyscyplinie otrzymał doktorat. Jego badania były uznawane za wybitne przez naukowców z całego świata. Jego żoną była Józefina Hoffmajster (6 IV 1905 - 4 XI 1987), córka rządcy dóbr majorackich Józefa i Wacławy z Tschirschnitzów Hoffmajstrów, zamieszkujących w dworku

78 J. Kozłowski, Battowie na wyższych i średnich szczeblach administracji Królestwa Polskiego w latach 1863-I9I4 ( $w$ zwiazku z artykutem Eukasza Chimiaka, Kariery tzw. Battów w rosyjskiej administracji Królestwa Polskiego w drugiejpotowie XIX w., PH t. LXXXVIII, I997, Z.3-4), „Przegląd Historyczny” 1999, t. 90, nr 2, s. 196.

79 Kronika, „Gazeta Warszawska”, 6 II I925, nr 47, s. 3; Szkodliwa nominacja, „Dziennik Bydgoski”, 3I VII 1926, nr 173, s. 2.

80 ATpu, Zaproszenie na ślub Eugeniusza hr. Tolla z Ludmiłą baronówną Tiesenhausen, zbiory nieuporządkowane; tamże, Listy Tatiany Yarigin, zbiory nieuporządkowane; G. Chmielewska, O Sergiuszu Tollu, potomku carskich generatów, który odkryt 279 gatunków motyli, „Gazeta Pomorska”, II II 2 OI2 r. Dostępny winternecie: https://pomorska.pl/o-sergiuszu-tollu-potomku-carskich-generalow-ktory-odkryl-279-gatunkow-motyli/ar/7268274. 
(rządcówce) w Uniejowie. Z kolei córka Sergiusza i Józefiny, Adelajda Toll, urodzona w Bydgoszczy w marcu 1927 r. ukończyła studia medyczne i była lekarką pediatrą ${ }^{81}$. Zawód medyczny wybrała także jej córka Aleksandra Toll-Bromboszcz (również pediatra) oraz wnuczka Anna. Potomkinie znakomitego entomologa mieszkają w Katowicach.

\section{Zakończenie}

Wspomniany na początku T. Wójcik swój niewielki, ale istotny tekst zakończył następującymi słowami: „Tollowie wrośli w historię Uniejowa w sposób mocny. Początkowo bezdyskusyjnie byli to zaborcy, w kolejnych pokoleniach nauczyli się żyć w zgodzie z miejscową ludnością, by wreszcie dzielić $\mathrm{z}$ Polakami ich narodowe tragedie. Niektórzy z nich na tej ziemi pozostali na zawsze" ${ }^{\$ 2}$. Z pewnością z ogólnym wydźwiękiem tej konstatacji można by się zgodzić, chociaż szczególnie byłbym ostrożny w formułowaniu słów „[...] by wreszcie dzielić z Polakami ich narodowe tragedie [...]?”. Ponadto w latach Drugiej Rzeczypospolitej żadne z dzieci ostatniego donatariusza nie pozostało w Uniejowie ani w regionie, gdyż wybrali inne miejsca osiedlenia się po utracie majoratu (Bydgoszcz, Warszawa, Katowice) i na tamtejszych nekropoliach spoczęli po śmierci. Z pewnością nie można podważać, iż „[...] wrośli w historię Uniejowa [...]", a władze i mieszkańcy miasta znakomicie starają się wyeksponować ten fakt, poszukując atrakcji dla setek turystów przyjeżdżających do tutejszych gorących wód. Na ile jednak rzeczywiście rodzina von Tollów związana była mentalnie z miastem i regionem, a nie wyłącznie posiadanym tutaj dziedzicznym majoratem? Nie uda się niestety odpowiedzieć na to pytanie, jeśli nie dysponujemy egodokumentami wytworzonymi przez członków tej rodziny.

8I hak., Niezwykte polowanie, „Dziennik Bydgoski”, I5 V 1932, nr III, s. I8; H. Reisser, Dr. Sergiusz (Graf von) Toll t, „Zeitschrift der Wiener Entomologischen Gesellschaft” 1962, 47, s. 79-8I; A. Diakonoff, Sergiusz Toll (I893-196I), "Journal of the Lepidopterists' Society” 1963, vol. 17, no. I, s. 47-49; Tablica epitafijna na pomniku małżeństwa Tollów na cmentarzu przy ul. Francuskiej w Katowicach; G. Kuźnik, Rodzina barwna jak motyle. Sergiusz Toll wiele nowych gatunków odkryt na Śląsku, „Dziennik Zachodni”, I8 IV 2013. Dostępny w internecie: https://dziennikzachodni.pl/rodzina-barwna-jak-motyle-sergiusz-toll-wiele-nowych-gatunkow-odkryl-na-slasku/ar/872421. Józef Hoffmajster zmarł bardzo wcześnie, żona Wacława wychowywała kilkoro dzieci - Wandę, Stefanię, Józefinę, Jana, Henryka. Jan i Henryk należeli do elity uniejowskiej i byli inicjatorami szeregu przedsięwzięć społecznych, gospodarczych i politycznych w Uniejowie.

82 T. Wójcik, dz. cyt., s. I5. 


\section{Bibliografia}

\section{Źródła archiwalne}

Archiwum Akt Nowych

Ministerstwo Rolnictwa i Dóbr Państwowych, Wydział Majątków Państwowych

Archiwum Główne Akt Dawnych

Komisja Rządowa Spraw Wewnętrznych

Komitety wystawowe, seria 2, Komitet Ogólny Wystawy Rolniczej w Warszawie

Archiwum Państwowe w Kaliszu

Naczelnik Powiatu Kaliskiego [Deutscher Kreischef in Kalisch] 1915-1918

Archiwum Państwowe w Łodzi

Rząd Gubernialny Kaliski

Rząd Gubernialny Piotrkowski, Wydział Administracyjny

Urząd Gubernialny Kaliski do Spraw Włościańskich

Archiwum Państwowe w Poznaniu. Oddział w Koninie

Akta hipoteczne Sądu Rejonowego w Turku

Archiwum Towarzystwa Przyjaciół Uniejowa

Listy Tatiany Toll-Yarigin

Protokoły przekazania folwarku Grzybki i lasu rządowego w obrębie Księże Młyny.

Umowa dotycząca objęcia kierownictwa gorzelni w Stemplewie przez Antoniego Su-

kiennickiego (1909).

Umowa o udzielenie plenipotencji dla Antoniego Sukiennickiego (1914).

Wypis z wykazu hipotecznego majątku „Zagaj-Mizerka” powiatu tureckiego z dn. I6 V I93I r.

Zaproszenie na ślub Eugeniusza hr. Tolla z Ludmiłą baronówną Tiesenhausen.

Wojewódzki Urząd Ochrony Zabytków

nr rejestru A/48I/222, Park w zespole zamkowo-pałacowym w Uniejowie

\section{Źródła drukowane}

„Dziennik Bydgoski” 1926, 1932, 1935

Dziennik Praw Królestwa Polskiego, t. 17, 20, 66

Dziennik Ustaw 1918, I919

„Gazeta Warszawska” 1925

Genealogisches Handbuch der baltischen Ritterschaften, Teil 2: Estland, Görlitz 1930.

„Kalendarz Myśliwski Ilustrowany na rok 1894”, Warszawa 1893.

„Kurier Warszawski” 19ı8

Mannerheim C.G., Wspomnienia, tłum. K. Szelągowska, Warszawa 2017.

Monitor Polski 1938

„Noworocznik Kaliski na rok przestępny I876”, Kalisz i875.

„Roczniki Gospodarstwa Krajowego” I86I

Stownik geograficzny Królestwa Polskiego i innych krajów stowiańskich, t. 2, Warszawa 188I; t. I0, Warszawa I889; t. II, Warszawa I890; t. I2, Warszawa 1892.

Список генералам по стариинству, исправлено по г мая гgII, Санкт Петербург гі1г.

Список генералам по стариинству, исправлено по г мая 1914, Санкт Петербург 1914.

\section{Opracowania}

Bernhardi von T., Denkwürdigkeiten aus dem Leben des Grafen von Toll, 2. Auflage, Leipzig 1866.

Bornstein B., Majoraty (donacje) w b. Królestwie Polskim, Warszawa Ig22 (odbitka z „Miesięcznika Statystycznego", wydawanego przez Główny Urząd Statystyczny Rzeczypospolitej Polskiej, rok I92I, tom IV). 
Cepil M., Figlus T., Geneza majoratu i stosunki osadnicze w dobrach rodziny Tollów pod Uniejowem, „Biuletyn Uniejowski” 2017, t. 6.

Chimiak Ł., Kariery tzw. Battów w rosyjskiej administracji Królestwa Polskiego w drugiej potowie XIX w., „Przegląd Historyczny” 1997, t. 88, nr 3-4.

Chmielewska G., O Sergiuszu Tollu, potomku carskich generatów, który odkryt 279 gatunków motyli, „Gazeta Pomorska”, II II 2012 r. Dostępny w internecie: https://pomorska.pl/o-sergiuszu-tollu-potomku-carskich-generalow-ktory-odkryl-279-gatunkow-motyli/ar/7268274.

Diakonoff A., Sergiusz Toll (I893-I96I), ,Journal of the Lepidopterists' Society” 1963, vol. I7, no. I.

Grabarczyk T., Kowalska-Pietrzak A., Szymczak J., Uniejowskie strony - karty z przesztości odlegtej, nieznanej i bliskiej gminy Uniejów, Łódź-Uniejów 2008.

Grabski W., Historia Towarzystwa Rolniczego 1858-1861, t. I-2, Warszawa 1904.

Hayward R.M., Russia Enters the Railway Age, $1842-1855$, New York 1998.

Kaczkowski J.P., Donacye w Królestwie Polskim, Warszawa 1917.

Kozłowski J., Battowie na wyższych i średnich szczeblach administracji Królestwa Polskiego w latach 1863-I9I4 (w związku zartykutem Eukasza Chimiaka, Kariery tzw. Battów w rosyjskiej administracji Królestwa Polskiego w drugiej potowie XIX w., PH t. LXXXVIII, 1997, Z. 3-4), „Przegląd Historyczny” 1999, t. 90, nr 2.

Kubiatowski J., Piasecki Julian Marian, [w:] Polski Stownik Biograficzny, t. 25, Wrocław 1980.

Kukulski J., Donacje paskiewiczowskie w okresie reform agrarnych, Kielce 1987.

Kukulski J., Generatowie carscy i ich majątki ziemskie w Królestwie Polskim (I835-I920), Warszawa 2007.

Kukulski J., System organizacji produkcji folwarcznej i zarzadzania dobrami donacyjnymi w Królestwie Polskim, „Acta Universitatis Lodziensis. Folia Historica” 1984, nr I8.

Kuźnik G., Rodzina barwna jak motyle. Sergiusz Toll wiele nowych gatunków odkryt na Ślasku, „Dziennik Zachodni”, I8 IV 20I3. Dostępny w internecie: https://dziennikzachodni.pl/rodzinabarwna-jak-motyle-sergiusz-toll-wiele-nowych-gatunkow-odkryl-na-slasku/ar/872421.

Pełka B., Lata zaborów, [w:] Uniejów. Dzieje miasta, red. J. Szymczak, Uniejów-Łódź 1995.

Połujański A., Opisanie lasów Królestwa Polskiego i Gubernij Zachodnich Cesarstwa Rosyjskiego pod względem historycznym, statystycznym i gospodarczym, t. I, Warszawa 1854 .

Reisser H., Dr. Sergiusz (Graf von) Toll t, „Zeitschrift der Wiener Entomologischen Gesellschaft" $1962, \mathrm{nr} 47$.

Szczepański B., Rozwój rolnictwa, [w:] Dzieje Wielkopolski, red. W. Jakóbczyk, t. 2, Poznań 1973.

Szwarc A., Wieczorkiewicz P., O roli tzw. Battów w dziejach Rosji wXIX i XX w. (Na marginesie ksiażki Maksyma M. Duchanowa), „Kwartalnik Historyczny” 1981, nr 4.

Tokarz W., Wojna polsko-rosyjska $1_{3}{ }_{3}$ i i $8_{31}$, Warszawa 1930.

Toll von Ch., Die Familie von Toll - eine Adelsfamilie im Ostseeraum. Dostępny w internecie: http://toll-europe.se/Artiklar/toll-runt-oestersjon-de.pdf.

Wójcik T., Tollowie, „W Uniejowie. Pismo Towarzystwa Przyjaciół Uniejowa” 2016, nr 67.

Zdyb M., Kaplica grobowa rodziny Tollów jako przyktad prawostawnego dziedzictwa w województwie tódzkim, „Biuletyn Uniejowski” 2017, t. 6.

Streszczenie: Po klęsce powstania listopadowego w przestrzeni wiejskiej Królestwa Polskiego pojawiły się donacje należące do rosyjskich wysokiej rangi oficerów i carskiej elity urzędniczej. Car Mikołaj I nadał im te dobra przede wszystkim za zasługi oddane podczas tłumienia polskiego powstania i wierną służbę. Jedną z największych donacji otrzymał generał piechoty Karol Wilhelm hrabia Toll, pochodzący z tzw. Bałtów (szlachty bałtyckiej). Był on jednym z najbardziej znaczących dowódców carskich w wojnie polsko-rosyjskiej w I83i r. Otrzymał on w i836 r. część dóbr skarbowych Uniejów o powierzchni ponad 5500 mórg. Donacja ta znajdowała się w posiadaniu rodziny von Tollów przez 80 lat. Po klęsce powstania styczniowego otrzymali oni jeszcze niewielką donację Grzybki. Ponadto byli właścicielami majątku ziemskiego Stemplew. Kolejne trzy pokolenia tej rodziny coraz 
bardziej wiązały się z regionem, a po utworzeniu niepodległej Rzeczypospolitej potomkowie pierwszego donatariusza pozostali w naszym kraju. Jednak nie byli już właścicielami donacji, którą przejęło państwo polskie w 1919 r. W pierwszej części niniejszego artykułu dokonano syntetycznej charakterystyki dóbr ziemskich będących w rękach hrabiów Tollów. Natomiast w drugiej części podjęto próbę odtworzenia genealogii uniejowskiej linii tego rodu oraz przybliżono nieraz skomplikowane losy potomków pierwszego donatariusza.

Słowa klucze: donacja, rodzina von Tollów, genealogia, Uniejów

Summary: After the defeat of the November Uprising, donations belonging to Russian high-ranking officers and the Tsar's official elite appeared in the rural space of the Kingdom of Poland. Tsar Nicholas I gave them these goods, above all for their services rendered during the suppression of the Polish uprising and faithful service. One of the biggest donations was received by infantry general Karol Wilhelm, count Toll, from the so-called Balts (Baltic nobility). He was one of the most significant tsarist commanders in the Polish-Russian war in I831. In I 836 he received part of Uniejów's treasury goods with an area of over 5,500 morgens. This donation was in the possession of the von Toll family for 80 years. After the defeat of the January Uprising, they received a small donation from Grzybki. In addition, they were owners of the Stemplew estate. The next three generations of this family were increasingly associated with the region, and after the creation of the independent Republic of Poland, the descendants of the first donor remained in our country. However, they were no longer the owners of the donation, which was taken over by the Polish state in 1919. In the first part of this article, a synthetic description of the land goods in the hands of the counts of the Tolls was made. In the second part, however, an attempt was made to reconstruct the genealogy of the Uniejów line of this family, and often presented the complicated fate of the descendants of the first donor.

Keywords: donation, von Toll family, genealogy, Uniejów 